\title{
Tampa Scale for Kinesiophobia
}

$1=$ strongly disagree

$2=$ disagree

$3=$ agree

$4=$ strongly agree

\begin{tabular}{|c|c|c|c|c|}
\hline 1. I'm afraid that I might injury myself if I exercise & 1 & 2 & 3 & 4 \\
\hline $\begin{array}{l}\text { 2. If I were to try to overcome it, my pain would } \\
\text { increase }\end{array}$ & 1 & 2 & 3 & 4 \\
\hline $\begin{array}{l}\text { 3. My body is telling me I have something } \\
\text { dangerously wrong }\end{array}$ & 1 & 2 & 3 & 4 \\
\hline $\begin{array}{l}\text { 4. My pain would probably be relieved if I were to } \\
\text { exercise }\end{array}$ & 1 & 2 & 3 & 4 \\
\hline $\begin{array}{l}\text { 5. People aren't taking my medical condition } \\
\text { seriously enough }\end{array}$ & 1 & 2 & 3 & 4 \\
\hline $\begin{array}{l}\text { 6. My accident has put my body at risk for the rest } \\
\text { of my life }\end{array}$ & 1 & 2 & 3 & 4 \\
\hline 7. Pain always means I have injured my body & 1 & 2 & 3 & 4 \\
\hline $\begin{array}{l}\text { 8. Just because something aggravates my pain does } \\
\text { not mean it is dangerous }\end{array}$ & 1 & 2 & 3 & 4 \\
\hline $\begin{array}{l}\text { 9. I am afraid that I might injure myself } \\
\text { accidentally }\end{array}$ & 1 & 2 & 3 & 4 \\
\hline $\begin{array}{l}\text { 10. Simply being careful that I do not make any } \\
\text { unnecessary movements is the safest thing I can } \\
\text { do to prevent my pain from worsening }\end{array}$ & 1 & 2 & 3 & 4 \\
\hline $\begin{array}{l}\text { 11. I wouldn't have this much pain if there weren't } \\
\text { something potentially dangerous going on in my } \\
\text { body }\end{array}$ & 1 & 2 & 3 & 4 \\
\hline $\begin{array}{l}\text { 12. Although my condition is painful, I would be } \\
\text { better off if I were physically active }\end{array}$ & 1 & 2 & 3 & 4 \\
\hline $\begin{array}{l}\text { 13. Pain lets me know when to stop exercising so } \\
\text { that I don't injure myself }\end{array}$ & 1 & 2 & 3 & 4 \\
\hline $\begin{array}{l}\text { 14. It's really not safe for a person with a condition } \\
\text { like mine to be physically active }\end{array}$ & 1 & 2 & 3 & 4 \\
\hline $\begin{array}{l}\text { 15. I can't do all the things normal people do } \\
\text { because it's too easy for me to get injured }\end{array}$ & 1 & 2 & 3 & 4 \\
\hline $\begin{array}{l}\text { 16. Even though something is causing me a lot of } \\
\text { pain, I don't think it's actually dangerous }\end{array}$ & 1 & 2 & 3 & 4 \\
\hline $\begin{array}{l}\text { 17. No one should have to exercise when he/she is in } \\
\text { pain }\end{array}$ & 1 & 2 & 3 & 4 \\
\hline
\end{tabular}




\section{Scoring Information}

\section{Tampa Scale for Kinesiophobia}

A total score is calculated after inversion of the individual scores of items $4,8,12$ and 16. 